\title{
BIBLIOGRAPHY
}

\author{
GENERAL ISSUES
}

\section{SOCIAL THEORY AND SOCIAL SCIENCE}

Beyond the Marketplace. Rethinking Economy and Society. Ed. by Roger Friedland and A. F. Robertson. [Sociology and Economics.] Aldine de Gruyter, New York 1990. vi, 365 pp. DM 120.00. (Paper: DM 62.00.)

The twelve essays in this collection present an interdisciplinary view of the relationship between markets and society. Contributions include, besides general theoretical dissertations about economic sociology and rational choice theory, articles about "Markets, Marriages, and Other Mates: The Problem of Power" (Paula England and Barbara Stanek Kilbourne), "Class Conflict as a Dynamic Game" (Michael Wallerstein), "A Complex Relationship: Family Strategies and the Processes of Economic and Social Change" (Tamara K. Hareven) and "States, Labor Markets, and Life Cycles" (John Myles).

Commons, John R. Institutional Economics. Its Place in Political Economy. With a New Introd. by Malcolm Rutherford. Transaction Publishers, New Brunswick [etc.] 1990. lxix, 921 pp. (2 vol. set). \$ 39.95.

Not only the tremendous amount of publications of John R. Commons (1862-1945) but also the reprint of Institutional Economics, originally published in 1934, show that the interest in the work of this labour economist has increased enormously. Commons' overall objective of this "difficult book" was to give institutional economics - by which he meant the study of "collective action in control of individual action" - its proper place in "the whole of a rounded-out theory of Political Economy". In Commons' system, collective action operates through "working rules": the body of statute and common law, customs, and common practices. These (changing) working rules affect economic outcomes by determining the nature of economic transactions undertaken by individuals and the terms on which they will be carried out.

The Development of Political Science. A Comparative Survey. Ed. by David Easton, John G. Gunnell and Luigi Graziano. Routledge, London [etc.] 1991. xii, 296 pp. $£ 40.00$.

The thirteen contributors to this collection present a survey of the development of political science "as a growing transnational body of knowledge" in North America, Western Europe, China and "Anglophone" Africa.

Fin du communisme? Actualité du marxisme? Sous la dir. de Jacques Bidet et Jacques Texier. Colloque international Sorbonne, 17-18-19 mai 1990, organisé par la revue Actuel Marx et l'Istituto italiano per gli studi fi- 
losofici. [Actuel Marx Confrontation.] Presses Universitaires de France, Paris 1991. F.fr. 170.00 .

These are the proceedings of a colloquium held at the Sorbonne in May 1990, focusing on the question to what extent the revolutions in Eastern Europe and the USSR signify the bankruptcy of Marxism/Communism. Among the authors are: Robin Blackburn, Max Gallo, Jacques Julliard, Alain Lipietz, Rossana Rossanda and Immanuel Wallerstein.

SCHÖLER, UlI. "Despotischer Sozialismus" oder "Staatssklaverei"? Die theoretische Verarbeitung der sowjetrussischen Entwicklung in der Sozialdemokratie Deutschlands und Österreichs (1917 bis 1929). [Politikwissenschaft, Band 7.] Lit, Münster 1990. xx, 1046 pp. (in 2 vols.) DM 168.00.

This voluminous doctoral thesis (Bremen, 1990) reconstructs the theoretical discussions about the development of the Soviet Union in the German and Austrian Social Democratic parties, 1917-1929. Naturally, ample attention is paid to the contributions of Max Adler, Otto Bauer, Karl Kautsky, Rosa Luxemburg and Julius Martov.

\section{HISTORY}

Henning, Friedrich-Wilhelm. Handbuch der Wirtschafts- und Sozialgeschichte im Mittelalter und in der frühen Neuzeit. Ferdinand Schöningh, Paderborn [etc.] 1991. xviii, 1090 pp. Ill. DM 268.00.

This bulky book is the first of a projected three-volume handbook on the economic and social history from prehistory until the present. The present volume dilates upon the "outlines of the development" until the end of the eighteenth century in Central Europe. Topics include: prehistory, early history, the genesis of feudalism, the founding of cities, eastern colonization, the burgeoning of urban economy (1350-1470), the age of the price revolution (1470-1618), and the flourishing of kameralism.

HobsBawm, E. J. Echoes of the Marseillaise. Two Centuries Look Back on the French Revolution. Verso, London [etc.] 1990. xv, 144 pp. $£ 24.95$. (Paper: $£$ 8.95.)

This small book contains the history of reception and interpretation of the French Revolution during the nineteenth en twentieth centuries. Rather than an incident Professor Hobsbawm considers the revolution as a process which transformed the world permanently and, as recent events in Eastern Europe emphasize, introduced ideas that continued to transform it: "The French Revolution gave peoples the sense that history could be changed by their action [ . . and] demonstrated the power of the common people in a manner which no subsequent government has ever allowed itself to forget." 
HobsBawm, E. J. Nations and nationalism since 1780. Programme, myth, reality. Cambridge University Press, Cambridge [etc.] 1990. viii, 191 pp. $£ 14.95$.

See Brian Jenkins's review in this volume, pp. 102ff.

New Perspectives on Historical Writing. Ed. by Peter Burke. Polity Press, Cambridge 1991. vii, 254 pp. $£ 35.00$.

The eleven essays in this collection examine new approaches to the writing of history. The contributions include "History from Below" (Jim Sharpe), "Women's History" (Joan Scott), "Overseas History" (Henk Wesseling), "On Microhistory" (Giovanni Levi), "Oral History" (Gwyn Prins), "History of Reading" (Robert Darnton), "History of Images" (Ivan Gaskell), "History of Political Thought" (Richard Tuck), "History of the Body" (Roy Porter) and "History of Events and the Revival of Narrative" (the editor).

Sources of the History of Africa, Asia and Oceania in Yugoslavia. Ed. by the Union of Societies of Archivists of Yugoslavia. [Guides to the Sources for the History of the Nations, 3rd Series, Vol. 10.] K. G. Saur, München [etc.] 1991. vii, 164 pp. DM 168.00.

The present volume gives "a survey of sources preserved primarily in the archives of Yugoslavia relating mainly to the Near East and North Africa, i.e. the lands within the Islamic cultural circle. [. . .] Only exceptionally do the documents listed in this Guide concern countries in the Far East, India, Eastern Asia, Australia and Sub-Saharan Africa".

Was ist Gesellschaftsgeschichte? Positionen, Themen, Analysen. Hrsg. von Manfred Hettling, Claudia Huerkamp, Paul Nolte [und] Hans-Walter Schmuhl. Verlag C. H. Beck, München 1991. 342 pp. DM 48.00.

The present Festschrift on the occasion of Professor Hans-Ulrich Wehler's sixtieth birthday contains over thirty short essays about a wide range of sociohistorical subjects, varying from "Ordo and dignitas as social categories in the Roman Republic" (Rolf Rillinger), via "Max Weber and the race problem" (the fourth editor) to the East European revolutions of 1989-1991 (Jürgen Kocka).

Women and Politics in the Age of the Democratic Revolution. Ed. by Harriet B. Applewhite and Darline G. Levy. The University of Michigan Press, Ann Arbor 1990. vii, 289 pp. Ill. $£ 25.00$.

The nine essays collected in this volume explore the participation of women in eighteenth-century rebellions in the United States, Belgium, England, France and the Netherlands. Included are studies about, among other subjects, the women's role in English food riots (John Bohstedt), in the French Revolution (Dominique Godineau, the editors), in revolutionary Brussels (Janet Polasky), in the American Revolution 1765-1776 (Alfred F. Young) and in the Dutch Patriot and Batavian revolutions (Wayne Ph. te Brake, Rudolf $\mathrm{M}$. Dekker and Lotte C. van de Pol). 
Women's Words. The Feminist Practice of Oral History. Ed. by Sherna Berger Gluck and Daphne Patai. Routledge, New York [etc.] 1991. vi, 234 pp. $£$ 35.00. (Paper: $£$ 10.99.)

This is a collection of thirteen essays devoted to exploring the theoretical, methodological and practical problems that arise when women utilize oral history as a tool of feminist scholarship. Topics include: interview techniques and analyses (Kathryn Anderson and Dana C. Jack), interpretative conflict in oral narrative research (Katherine Borland), the practice of oral history among working-class women and men (Karen Olson and Linda Shopes) and scholarly collaboration and community outreach (Laurie Mercier and Mary Murphy).

\section{COMPARATIVE HISTORY}

BlackBurn, Robin. The Overthrow of Colonial Slavery 1776-1848. Verso, London [etc.] 1988. ix, 560 pp. Ill. Maps. £ 27.95.

This is a wide-ranging analytical narrative seeking to reconstruct the causes of the abolishment of slavery in the Americas in the late eighteenth and nineteenth centuries. The author draws the conclusion that slave emancipation triumphed in this period when three factors favourable to such an outcome coincided: "(i) a political crisis marginalising slaveholders and giving birth to a new type of state; (ii) the actuality or prospect of slave resistance or rebellion; (iii) social mobilisations encouraging the partisans of reform or revolution to rally popular sentiment with anti-slavery acts."

FARHI, FARIDEH. States and Urban-Based Revolutions. Iran and Nicaragua. University of Illinois Press, Urbana [etc.] 1990. x, 147 pp. \$29.95.

See Charles Tilly's review in this volume, pp. $105 \mathrm{ff}$.

Gerber, Haim. Islam, Guerrilla War, and Revolution. A Study in Comparative Social History. Lynne Rienner Publishers, Boulder [etc.] 1988. v, 209 pp. \$28.50.

See Rod Aya's review in this volume, pp. 91ff.

Income distribution in historical perspective. Ed. by Y. S. Brenner, Hartmut Kaelble [and] Mark Thomas. Cambridge University Press, Cambridge [etc.]; Editions de la Maison des Sciences de l'Homme, Paris 1991. xv, 261 pp. $£ 30.00$.

The nine contributions in this collection deal with some of the central long-term issues raised by the problems of income distribution. The Kuznets curve-i.e. the notion that income distribution became increasingly unequal during the period of industrialization and progressively less unequal during the drive to maturity lies at the basis of much of the analysis. Included are cases studies of Sweden (Johan Söderberg), Belgium (Peter Scholliers), Germany (Rolf Dumke), Australia (the third editor) and the United States (Ian W. McLean). 
Innere Staatsbildung und gesellschaftliche Modernisierung in Österreich und Deutschland 1867/71 bis 1914. Historikergespräch Österreich - Bundesrepublik Deutschland 1989. Hrsg. von Helmut Rumpler. Verlag für Geschichte und Politik, Wien 1991; R. Oldenbourg Verlag, München. 288 pp. S 396.

These proceedings of a conference about state formation and state policies in Austria and Germany (Vienna, 1989) contain, among other things, contributions on Staatsbewußtsein, state symbolism and social policies. In addition, studies have been included about "Austria-Hungary from the point-of-view of the German Empire" (Wolfgang J. Mommsen) and "The German Empire from the point-of-view of Austria-Hungary" (the editor).

Landgemeinde und Stadtgemeinde in Mitteleuropa. Ein struktureller Vergleich. Hrsg. von Peter Blickle. Redaktion: André Holenstein. R. Oldenbourg Verlag, München 1991. vi, 508 pp. DM 148.00.

This book contains the proceedings of a conference about urban and agricultural communities in Central Europe during the late middle ages and the early modern period, held in Schloss Reisensburg (Germany) in March 1989. The over twenty contributions cover theoretical-conceptual, regional and systematic studies.

MCDaniel, Tim. Autocracy, Modernization, and Revolution in Russia and Iran. Princeton University Press, Princeton 1991. ix, 239 pp. \$29.95.

This comparative study of the Russian revolution of 1917 and the Iranian revolution of 1978-1979 explores the dilemmas inherent in the efforts of autocratic monarchies to transform their countries into modern industrial societies - and to do so at a rapid pace. Professor McDaniel's central argument is that autocratic modernization is a fourth way to modernity by the side of the three identified in Barrington Moore's Social Origins of Democracy and Dictatorship (i.e., bourgeois, conservative and peasant revolutions).

Massenmedium Strasse. Zur Kulturgeschichte der Demonstration. Hrsg. von Bernd Jürgen Warneken. Campus Verlag, Frankfurt [etc.]; Editions de la Maison des Sciences de l'Homme, Paris 1991. 283 pp. Ill. Maps. DM 39.80.

In this collection of thirteen essays mass demonstrations in France and Germany are discussed through historical case studies. The subjects include demonstrations in Lyon, 1848, 1890, 1912 (Vincent Robert), in the German Kaiserreich (the editor), and in Paris between the world wars (Danielle Tartakowsky). Attention is also paid to funeral rituals of the German social democracy in the 1870s and 1880s (Alf Lüdtke) and of the French Communists (Jean-Pierre A. Bernard) as well as to Labour Day manifestations (Miguel Rodriguez, Peter Friedemann).

Policing the empire. Government, Authority and Control, 1830-1940. Ed. by David M. Anderson and David Killingray. [Studies in Imperialism.] 
Manchester University Press, Manchester [etc.] 1991; distr. exclusively in the USA and Canada by St. Martin's Press, New York. xii, 260 pp. Ill. $£ 40.00$.

The fourteen contributions to this collection of essays deal with the British colonial police forces as agents of imperial and settler power. Included are, inter al., case studies about Ireland, Queensland, New Zealand, the British Caribbean, Canada, the Gold Coast, rural India, the Sudan, South Africa and Kenya.

Revolution und Gegenrevolution 1789-1830. Zur geistigen Auseinandersetzung in Frankreich und Deutschland. Hrsg. von Roger Dufraisse unter Mitarb. von Elisabeth Müller-Luckner. [Schriften des Historischen Kollegs, Kolloquien 19.] R. Oldenbourg Verlag, München 1991. xix, 274 pp. DM 88.00.

The sixteen contributions to this volume have previously been presented on a colloquium of the Historische Kolleg in Munich, April 1988. These historical case studies on political views in Germany and France in the decades after the French revolution include names as Pestalozzi (Peter Stadler), C. F. D. Schubart (Jean Clédière), Knigge and Zimmermann (Pierre-André Bois), De Maistre (Jean Tulard), Karl von Rotteck (Jürgen Voss), Decazes (Jean Benoît Yvert) and Lamartine (Fernand L'Huillier).

Revolutionary Syndicalism. An International Perspective. Ed. by Marcel van der Linden and Wayne Thorpe. Scolar Press, Aldershot 1990. xi, 260 pp. $£ 32.50$.

See Erik Olssen's review in this volume, pp. 107ff.

\section{CONTEMPORARY ISSUES}

After the Fall. The Failure of Communism and the Future of Socialism. Ed. by Robin Blackburn. Verso, London [etc.] 1991. xvi, 327 pp. $£ 34.95$. (Paper: £ 10.95.)

The twenty essays in this book (all published before) explore the historical meaning of Communism's "meteoric trajectory" across the twentieth century. Included are, inter alia, a debate between Fred Halliday and Edward Thompson on "The Ends of Cold War", Eric Hobsbawm's "Goodbye to All That", the editor's "Fin de Siècle: Socialism after the Crash", "Marxist Century, American Century" by Giovanni Arrighi and "The New Agenda" by André Gorz. 


\title{
CONTINENTS AND COUNTRIES
}

\section{AFRICA}

\begin{abstract}
Algeria
MARAN, Rita. Torture. The Role of Ideology in the French-Algerian War. Praeger, New York [etc.] 1989. xi, 214 pp. $£ 34.50$.

This book probes the role of ideology in legitimating the use of torture by successive French governments in their attempts to suppress the Algerian war of liberation. Dr Maran analyzes the contradiction between France's "civilizing" mission and its persisent use of torture throughout the war (1954-1962). Special attention is paid to the "discourses" of the governments, the military and the intellectuals.
\end{abstract}

\section{Nigeria}

Temperley, Howard. White Dreams, Black Africa. The Antislavery Expeditions to the River Niger 1841-1842. Yale University Press, New Haven [etc.] 1991. xv, 204 pp. Ill. \$ 40.00; £ 19.95.

In 1841 British antislavery crusaders launched a "civilizing" expedition to the Niger, seeking to cut off the slave trade at its source and make amends for past wrongs by carrying trade, civilization and Christianity into the African heartland. Professor Temperley tells the story of this "bizarre and ultimately tragic" expedition and its aftermath, providing the first scholarly account since the participants published their own experiences in the $1840 \mathrm{~s}$.

\section{South Africa}

Holding Their Ground. Class, Locality and Culture in 19th and 20th Century South Africa. Ed. by Philip Bonner, Isabel Hofmeyr, Deborah James and Tom Lodge. [History Workshop 4.] Witwatersrand University Press, Johannesburg; Ravan Press, Johannesburg 1989. xiv, 318 pp. Ill. R 34.95.

The nine essays collected in this volume have been presented before at the South African 1987 History Workshop. Topics include: "The ICU, the Labouring Poor and the Making of a Popular Political Culture in Durban, 1925-1930" (Paul la Hausse), "Johannesburg's African Middle Classes and the Question of Night Passes for African Women, 1920-1931" (Kathy Eales), the failure of Bantu education as an hegemonic strategy, 1955-1976 (Jonathan Hyslop), and "The Ndzundza Ndebele: Indenture and the Making of Ethnic Identity, 1883-1914" (Peter Delius).

\section{Tanzania}

Kimambo, Isaria N. Penetration \& Protest in Tanzania. The Impact of the World Economy on the Pare 1860-1960. [Eastern African Studies.] James Currey, London 1990; Tanzania Publishing House, Dar es Salaam; Heine- 
mann Kenya, Nairobi; Ohio University Press, Athens. xii, 188 pp. Ill. Maps. $£$ 25.00. (Paper: $£$ 9.95.)

Using oral-history methods the present study analyzes the history of the impact of the world economy in northeastern Tanzania. First under the pressures of commodity trade, and later under German and British imperialism, the peasant producers of this region were forced into participation in capitalist production. These partial changes destroyed the Pare's balanced subsistence structure. But throughout the colonial period the peasants were frustrated in their efforts to transform themselves fully into capitalist producers. These struggles finally led to open revolt in 1947 .

\section{AMERICA}

ANDREws, GregG. Shoulder to Shoulder? The American Federation of Labor, the United States, and the Mexican Revolution 1910-1924. University of California Press, Berkeley [etc.] 1991. vii, 272 pp. \$45.00.

The attitude of the American Federation of Labor towards the Mexican Revolution, 1910-1924, is the subject of this study. The authors show that the AFL leaders followed a complex logic, which led them, on the one hand, to support the aspirations of the Mexican workers and, on the other hand, to contribute to Mexico's deepening economic dependence on the United States. While offering encouragement on all "bread and butter" issues, they nevertheless facilitated a rudimentary consensus among U.S. labour, capital and government, which later made possible the growth of tripartite structures designed to maintain U.S. hegemony in Latin America.

\section{Cuba}

Allahar, Anton L. Class, Politics, and Sugar in Colonial Cuba. [Caribbean Studies, Vol. 2.] The Edwin Mellen Press, Lewiston [etc.] 1990. xi, 217 pp. \$49.95.

Analyzing the economic and political challenges facing the Cuban planters class during the early and middle years of the nineteenth century, the present book attempts to explain the reasons why the sugar sector and other related parts of the economy were prevented from developing freely along capitalist lines. The author's hypothesis is "that the colonial subordination of the local Cuban planters to (a) the Spanish Crown, and (b) the class of foreign merchants, whose long-term interests went counter to those of the planters, was directly responsible for the pattern of industrial and economic stagnation which resulted".

\section{United States of America}

ARnesen, ERIC. Waterfront Workers of New Orleans. Race, Class, and Politics, 1863-1923. Oxford University Press, New York [etc.] 1991. xiii, 353 pp. Ill. $£ 35.00$.

Focusing on industrial and race relations along the Mississippi waterfront from the Civil War to the early twentieth century's age of segregation, the present 
book compares the racially flexible 1880 s with the racially violent 1890 s. Exploring the political culture that alternately encouraged and discouraged biracial collaboration and the rise and fall of two biracial labour federations (the Cotton Men's Executive Council from 1880 to the early 1890s and the Dock and Cotton Council from 1901 to 1923) Dr Arnesen examines the role of black unions in the city's larger African-American social network and the connection between race relations and union work rules.

Avrich, Paul. Sacco and Vanzetti. The Anarchist Background. Princeton University Press, Princeton 1991. x, 265 pp. Ill. \$24.95.

In the present book Professor Avrich looks at the Sacco-Vanzetti affair from a new perspective. Rather than focusing on the trial and related issues, he tells the stories of Nicola Sacco, a shoe worker, and Bartolomeo Vanzetti, a fish peddler. Beginning with the childhood of the defendants in Italy, the author analyzes many aspects of their lives: the reasons for their emigration, their experiences in the USA, their activities in the anarchist movement.

Cohen, Lizabeth. Making a New Deal. Industrial Workers in Chicago, 1919-1939. Cambridge University Press, Cambridge [etc.] 1990. xviii, 526 pp. Ill. $£ 30.00$.

"During the depression of the 1930s, American workers changed the course of industrial relations and electoral politics for the rest of the twentieth century. [. . . ] Strong unions and a strong state became the new ideals of working people who, as recently as the 1920 s, had depended for survival on their ethnic and racial communities and weifare capitalist employers." On the basis of a Chicago case study the present book examines how it was possible and what it meant for ordinary workers to become effective unionists and national political participants by the mid-1930s.

Epstein, Barbara. Political Protest and Cultural Revolution. Nonviolent Direct Action in the 1970s and 1980s. University of California Press, Berkeley [etc.] 1991. xiii, 327 pp. Ill. \$24.95.

From her perspective of both a participant and an observer, Professor Epstein examines the nonviolent direct action movement that, inspired by the civil rights movement, flourished in the United States from the mid-1970s to the mid-1980s. She describes how the movement galvanized originally in opposition to nuclear power, with the Clamshell Alliance in New England and then the Abalone Alliance in California leading the way. The author thinks that the movement, whose influence soon spread, developed a fresh, innovative philosophy and style of politics that shaped the thinking of a new generation of activists.

Faue, Elizabeth. Community of Suffering \& Struggle. Women, Men, and the Labor Movement in Minneapolis, 1915-1945. [Gender \& American Culture.] The University of North Carolina Press, Chapel Hill [etc.] 1991. xviii, 295 pp. Ill. \$ 42.95. (Paper: \$16.45.)

The view of the author of the present book is that recent scholarship in labour 
history has been characterized by "two models of unionism": one focusing on the community, the other on shopfloor militancy. She argues that this dichotomy can be overcome by integrating the connections between productive and reproductive labour in the analysis and by assuming that there always have been shifts toward and away from the community. Dr Faue shows in her monograph how unions during the Great Depression in Minneapolis initially demonstrated "breadth in their commitment to community and workplace action", and how, by the late $1930 \mathrm{~s}$, "prolonged unemployment and preparations for war increasingly threatened community-based and locally led unions".

Goldberg, Robert A. Grassroots Resistance. Social Movements in Twentieth Century America. Wadsworth Publishing Company, Belmont (Cal.) 1991. xiii, 313 pp. £ 15.50.

Using the research mobilization approach as a framework, this book investigates eight twentieth-century left and right-wing US-American social "movements": the Anti-Saloon League, the Industrial Workers of the World, the $\mathrm{Ku} \mathrm{Klux}$ Klan, the Communist party, the John Birch Society, the Student Nonviolent Coordinating Committee, the Berkeley Free Speech Movement and the National Organization of Women. The purpose of these historical case studies is "to flesh out sociological conceptions of how movements mobilize".

Guarneri, Carl J. The Utopian Alternative. Fourierism in NineteenthCentury America. Cornell University Press, Ithaca [etc.] 1991. xvi, 525 pp. IIl. \$36.25.

American Fourierism inspired a sizable body of radical literature, many local clubs and over two dozen cooperative communities or "phalanxes". In this substantial narrative Professor Guarneri traces the American Fourierist movement from its roots in the religious, social and economic upheavals of the $1830 \mathrm{~s}$, through its communal experiments in the 1840 s, to its lingering twilight after the Civil War. He argues that Fourierist communitarianism was not a colourful sideshow to the main events of American history, but a serious and influential attempt to restructure the emergent society of individualism along cooperative lines.

Halker, Clark D. For Democracy, Workers, and God. Labor SongPoems and Labor Protest, 1865-95. [The Working Class in American History.] University of Illinois Press, Urbana [etc.] 1991. xiii, 243 pp. $\$ 29.95$.

Labour song-poems virtually disappeared in the United States after 1900. But for thirty years working-class Americans used these song-poems to offer an explicit challenge to industrial capitalism and to chart an alternative path for the nation's future. In the present book Dr Halker examines the songs and poetry in which Gilded Age workers gave voice to their aspirations and frustrations. He shows how these outpourings were influenced by the ethnic backgrounds, the political and religious beliefs and the daily experiences of the members of the postbellum labour movement. 
Hanging by a Thread. Social Change in Southern Textiles. Ed. by Jeffrey Leiter, Michael D. Schulman, and Rhonda Zingraff. ILR Press, Ithaca 1991. viii, 248 pp. \$32.00. (Paper: \$14.95.)

This book brings together eleven essays of sociologists and historians on textiles and textile workers in the southern United States. Among the topics dealt with are: the origins of paternalism in North Carolina's mills, 1836-1880 (Gary R. Freeze), paternalism in the Cone Mills of Greensboro, 1925-1930 (Bryant Simon), the 1958 Harriet-Henderson textile strike (Linda Frankel), robotics, electronics and the American textile industry (Julia C. Bonham) and the deindustrialization of the textile south (John Gaventa and Barbara Ellen Smith).

Immigrant Radicals. The View from the Left. Ed. by George E. Pozzetta. [American Immigration and Ethnicity, Vol. 9.] Garland Publishing, Inc., New York [etc.] 1991. xiv, 442 pp. Ill. \$62.00.

This collection contains a selected cross section of nineteen of the most significant articles, previously published in academic journals, dealing with immigrant workers and American labour radicalism. Among the contributors are Paul Buhle, Melvyn Dubofsky, Eric Foner, Charles Leinenweber and Sally M. Miller.

Lankton, Larry. Cradle to Grave. Life, Work, and Death at the Lake Superior Copper Mines. Oxford University Press, New York [etc.] 1991. xiii, 319 pp. Ill. $£ 35.00$.

This book tries to tell the "broad history" of the Lake Superior copper district in northern Michigan from its discovery in the first half of the nineteenth century until its final demise about 1970. Dr Lankton examines the technologies used and the work done underground in the mines, but is equally concerned with the communities on the surface and how company paternalism maintained social control of the work force. The author focuses his attention on the tensions and conflicts during the critical period from 1890 to 1920.

Ma, L. Eve Armentrout. Revolutionaries, Monarchists, and Chinatowns. Chinese Politics in the Americas and the 1911 Revolution. University of Hawaii Press, Honolulu 1990. xii, 227 pp. Ill. \$28.00.

This monograph deals with the rise of Chinese political parties in North American and Hawaiian Chinese communities at the beginning of this century. The author pays attention not only to the movement pro Sun Yat-sen, but also to the growth and development of the radical reform party of K'ang Yu-wei and Liang Ch'i-ch'ao. She shows that competition between radical reformers, pro-Sunrevolutionaries and other political groups greatly influenced the involvement of Chinese immigrants in the 1911 revolution and produced substantial changes in the overseas communities themselves.

McFeely, William S. Frederick Douglass. W. W. Norton \& Company, New York [etc.] 1991. xiii, 465 pp. Ill. \$ 30.00. 
In this biography of Frederick Douglass (1818-1895) the author, who previously won the Pulitzer Prize for his Grant: A Biography, tells in glowing terms the life story of the ex-slave who escaped bondage, emerged as one of the nineteenth century's most eloquent orators and writers, and became an inspring leader of the antislavery movement in the United States.

The Radical Women's Press of the 1850s. Ed. by Ann Russo and Cheris Kramarae. [Women's Source Library.] Routledge, New York [etc.] 1991. Ill. $£ 45.00$.

The present volume contains excerpts from six radical feminist US-American journals of the 1850s: The Lily, The Genius of Liberty, The Pioneer and Woman's Advocate, The Una, The Woman's Advocate and The Sybil. These writings by, about and for women reveal "a striking array of the feminist concerns of the 1850s". Biographical data on contributors have been appended.

Toward a Social History of the American Civil War. Exploratory Essays. Ed. by Maris A. Vinovskis. Cambridge University Press, Cambridge [etc.] 1990. xii, 201 pp. $£ 25.00$. (Paper: $£ 8.95$.)

See Earl F. Mulderink, III's review in this volume, pp. 109ff.

Unions and Immigrants. Organization and Struggle. Ed. by George E. Pozzetta. [American Immigration and Ethnicity, Vol. 7.] Garland Publishing, Inc., New York [etc.] 1991. xiv, 350 pp. Ill. \$55.00.

This collection brings together a selected cross section of sixteen of the most significant articles, previously published in academic journals, on trade unions and immigrant workers in the United States. The case studies include tradeunion exclusion or inclusion of Filipino, Italian, Chinese, Slavic, Jewish, Cuban and other ethnic groups.

The Work Experience. Labor, Class, and Immigrant Enterprise. Ed. by George E. Pozzetta. [American Immigration and Ethnicity, Vol. 6.] Garland Publishing, Inc., New York [etc.] 1991. xiv, 509 pp. Ill. \$ 72.00.

This collection contains a selected cross section of twenty-one of the most significant articles on the work experience of immigrant workers in the United States, previously published in academic journals. Among the contributors are John Bodnar, Edna Bonacich, Herbert G. Gutman, Paul Ong, Daniel T. Rodgers and Robert Sean Wilentz.

\section{ASIA}

\section{China}

Dirklik, ARIF. Anarchism in the Chinese Revolution. University of California Press, Berkeley [etc.] 1991. x, 326 pp. \$ 39.95.

This is the first comprehensive study of Chinese anarchism in a Euro-American 
language. Professor Dirlik argues that anarchism has had a threefold significance in twentieth-century Chinese history. First, anarchism was the most important current in social revolutionary thought between 1905 and 1925 . Second, during this formative period in the enunciation of a revolutionary discourse, anarchist ideas of revolution influenced the thinking of other revolutionaries, including later Marxists (among them Mao Zedong). Finally, by defining revolution as an open-ended socio-cultural activity, anarchists pointed to the transformation of everyday social relations as the ultimate task of revolution. A part of the book was published earlier in IRSH, XXXIV (1989).

\section{Iraq}

The Iraqi Revolution of 1958. The Old Social Classes Revisited. Ed. by Robert A. Fernea and Wm. Roger Louis. I. B. Tauris \& Co. Ltd, London [etc.] 1991. xxiv, 232 pp. $£ 35.00$.

In 1958 a group of nationalist officers of the Iraqi army overthrew the monarchy and established a republican regime. This collection of twelve essays assesses "the causes and the social, political and economic consequences of the revolution which destroyed the old social order and led, after a protracted struggle, to the rule of the Baath Party".

\section{Israel - Palestine}

Kamen, Charles S. Little Common Ground. Arab Agriculture and Jewish Settlement in Palestine, 1920-1948. University of Pittsburgh Press, Pittsburgh 1991. xi, 327 pp. \$39.95.

This analysis of Arab agriculture in Palestine reexamines some of the conventional interpretations of the structure of Arab Palestine during the British Mandate. Dr Kamen does so by setting the accepted analysis against an account of actual social and economic conditions of Arab society and the pressures to which that society was subjected. His conclusion is "more ambiguous than partisans might prefer": "the economic, social, and political context in which Arabs and Jews struggled with their competing claims to the land, and all they implied, greatly limited the available solutions".

\section{Japan}

KINZLEY, W. DEAN. Industrial harmony in modern Japan. The invention of a tradition. [The Nissan Institute/Routledge Japanese Studies Series.] Routledge, London [etc.] 1991. xvii, 190 pp. $£ 35.00$.

Economic success in Japan has been attributed to the existence of an assumed spirit of harmony between managers and workers. The present book argues that this "culture of harmony" was consciously invented and developed since the last decades of the nineteenth century. Very important in this process was a semibureaucratic organization called the Kyōchōkai (The Cooperation and Harmony Society) established in 1919. Dr Kinzley discusses the forces leading to the creation of the Kyōchókai, the key ideas of the organization's founders and leaders, the social and institutional reforms pursued and the changes in the 
organization, its ideology and programmes brought on by the world depression and national crisis of the 1930s.

\title{
AUSTRALIA AND OCEANIA
}

\begin{abstract}
Australia
Ellem, Bradon. In Women's Hands? A History of Clothing Trades Unionism in Australia. [The Modern History Series.] New South Wales University Press, Kensington 1989. xiv, 333 pp. Ill. A $\$ 24.95$.

This revised version of a doctoral thesis (Wollongong, 1986) contains a narrative history of the Clothing and Allied Trades' Union from its establishment in 1907 to the present day. The author shows that the formation of the CATU came about largely as a response to the federal arbitration system. With its origins in male-dominated, craft-based associations, the control of the union remained for most of its history in the hands of male officials despite the fact that it was a "women's union". It was only from the late 1970s, as some women gained access to positions of power, that the union's response to the broad base of its membership changed.
\end{abstract}

The Foundation of Labor. Ed. by Michael Easson. Pluto Press Australia Ltd, Leichhardt 1990. x, 82 pp. Ill. A\$ 9.95.

"This booklet aims to celebrate and critically reflect on the significance of that occasion in November 1890 when a group of workers voted to form the Labor Party." Among the subjects dealt with are: the resolutions adopted by the Labor Council of New South Wales in 1890 (Bede Nairn), the importance of the Great Strike of 1890 in determining the formation of the Labor Party (Graham Freudenberg) and early educational activities (Dick Hall).

\section{EUROPE}

Economy and Society: European Industrialisation and its Social Consequences. Essays presented to Sidney Pollard. Ed. by Colin Holmes and Alan Booth. Leicester University Press, Leicester [etc.] 1991. xxvii, 214 pp. $£ 35.00$.

The present Festschrift marks Professor Sidney Pollard's retirement. In addition to biographical and bibliographical information about the scholar honoured the collection contains eleven contributions about varying subjects like Gerschenkron's industrialization model (David S. Landes), British investment in interwar Czechoslovakia (Alice Teichova), the social history of the early German labour movement (Jürgen Kocka), working-class women in nineteenth-century Britain (John Saville) and the Paris building regulations of 1902 (Anthony Sutcliffe).

Landownership and Power in Modern Europe. Ed. by Ralph Gibson and Martin Blinkhorn. HarperCollinsAcademic, London 1991. v, 265 pp. Maps. $£ 40.00$. 
The twelve case studies collected in this volume are mostly of a local or regional nature and deal with the exercise of power by landowners in France, Germany, Italy, Spain, Britain and Ireland, from the late eighteenth century to the midtwentieth. The editors introduce the book by a clear essay that provides a systematic framework for the analysis of power in a rural society.

Medicine and Charity Before the Welfare State. Ed. by Jonathan Barry and Colin Jones. [Studies in the Social History of Medicine.] Routledge, London [etc.] 1991. x, 259 pp. $£ 45.00$.

The present collection of thirteen essays offers a broad perspective on the relationship between charity and medicine in Western Europe between the Middle Ages and the Advent of welfare states in the twentieth century. Among the subjects treated are: hospitals in Renaissance Florence (Katharine Park), medical charities in eighteenth-century London (Donna Andrew), medical charity in Hamburg, 1788-1815 (Mary Lindemann) and mutual-aid societies in nineteenth-century France (Allan Mitchell).

\section{Austria}

Eisenbach-Stangl, Irmgard. Eine Gesellschaftsgeschichte des Alkohols. Produktion, Konsum und soziale Kontrolle alkoholischer Rauschund Genußmittel in Österreich 1918-1984. [Studien zur Historischen Sozialwissenschaft, Band 17.] Campus Verlag, Frankfurt 1991. 406 pp. DM 78.00.

This is a comprehensive history of the production and consumption of alcohol in Austria from 1918. The author presents an extensive study of the brewery industry, viniculture, distillery, regional and gender-specific drinking habits, alcohol in the socialization process, addiction to alcohol, alcohol taxation and government attempts to regulate the use of alochol.

\section{Belgium}

De christelijke arbeidersbeweging in België 1891-1991. Onder red. van Emmanuel Gerard. [KADOC-Studies 11.] Deel 1. Deel 2. Universitaire Pers Leuven, Leuven 1991. 387 pp.; 624 pp. Ill. B.fr. 1950.00.

In the $1960 \mathrm{~s}, \mathrm{~S}$. H. Scholl published a three-volume study on the history of the Catholic labour movement in Belgium (see IRSH, XII (1967), p. 331). Dealing with the same subject, the two volumes, edited by Dr Gerard, integrate the enormous amount of social-historical studies conducted in the intervening years. Unlike the title suggests, the first volume presents a general narrative survey of the currents in the period from the second half of the nineteenth century until 1973; the second volume describes the developments of different forms of organizations (mutual aid societies, trade unions, co-operatives, etc.).

\section{France}

Derfler, Leslie. Paul Lafargue and the Founding of French Marxism 
1842-1882. Harvard University Press, Cambridge (Mass.) [etc.] 1991. x, 285 pp. Ill. £ 31.95 .

This partial biography surveys a part of the life and experiences of Paul Lafargue (1842-1911), who "was the first Marxist to sit in the French legislature and for three decades served as the chief theoretician and propagandist for Marxism in France". At the same time a picture is drawn of the development of Marxist socialism in France until the foundation of the Parti Ouvrier in 1882.

Duroy, Jean-Pierre. La compagnonnage aux sources de l'économie sociale. Préface de François Soulage. Mutualité Française, Paris 1991. 135 pp. F.fr. 75.00.

This is a very concise sketch of the French compagnonnage from the eleventh century as a prehistory to the nineteenth-century co-operatives and mutualbenefit societies.

Margadant, Jo Burr. Madame le Professeur. Women Educators in the Third Republic. Princeton University, Princeton 1990 . xii, 358 pp. $\$ 49.50$. (Paper: \$ 16.95.)

This is a prosopography of 213 women who were trained as schoolteachers at the School of Sèvres in the years 1881-1890. The book chronicles the young adulthood and early careers, professional mid-life and ageing of this first generation of female professeurs.

Mrtchell, Allan. The Divided Path. The German Influence on Social Reform in France after 1870. The University of North Carolina Press, Chapel Hill [etc.] 1991. xx, 410 pp. \$ 49.50.

Previously Professor Mitchell published The German Influence in France after 1870: The Formation of the French Republic (1979) and Victors and Vanquished:

The German Influence on Army and Church in France after 1870 (1984). The present book completes the trilogy on the German influence in France between 1870 and 1914, focusing on the French response to the pathbreaking social legislation passed during the 1880 s in Imperial Germany. The author shows that certain key problems of public health and welfare found different solutions in France and Germany, and he attempts to explain why the differences emerged.

Nationhood and Nationalism in France. From Boulangism to the Great War 1889-1918. Ed. by Robert Tombs. HarperCollins Academic, London 1991. xv, 286 pp. $£ 35.00$.

The twenty essays in this collection examine three major aspects of French nationalism: the complexities of the national culture within which the ideology existed, its political expressions and the impact of nationalism on significant areas of state policy. Topics include "Joan of Arc between right and left" (Gerd Krumeich), "Words and images of nationhood" (Pierre Sorlin), "The Jeunesse Antisémite et Nationaliste, 1894-1904" (Bertrand Joly), sports societies and nationalism, 1870-1914 (Pierre Arnaud) and "The army and the appel au soldat, 
1874-89" (Jean-Charles Jauffret).

RAPPOPORT, ChARLes. Une vie révolutionnaire, 1883-1940. Les mémoires de - Textes établi et annoté par Harvey Goldberg [et] Georges Haupt. Édition achevée et prés. par Marc Lagana. Editions de la Maison des sciences de l'homme, Paris 1991. v, 513 pp. Ill. F.fr. 190.00.

These are the memoirs of Charles Rappoport (1865-1941), a Marxist philosopher and journalist born in Russia, who left his native country for political reasons and came to France via Switzerland and became one of the founders of the French Communist Party. The edition is annotated, illustrated and provided with an index to persons.

Rewriting the French Revolution. The Andrew Browning Lectures 1989. Ed. by Colin Lucas. Clarendon Press, Oxford 1991. xi, 209 pp. $£ 30.00$.

The eight essays in this volume originated as a series of lectures given in the University of Oxford in 1989 in order to mark the bicentenary of the French Revolution. The contributions include: "The Forbidden Books of Pre-revolutionary France" (Robert Darnton), "The French Revolution or Pure Democracy" (François Furet), "Bourgeois Revolution Revivified: 1789 and Social Change" (Colin Jones), "The Adventures of Reason, or From Reason to the Supreme Being" (Michel Vovelle), and "Regionalism and Counter-Revolution in France" (Alan Forrest).

Wishnia, Judith. The Proletarianizing of the Fonctionnaires. Civil Service Workers and the Labor Movement Under the Third Republic. Louisiana State University Press, Baton Rouge [etc.] 1990. xi, 394 pp. $£ 16.10$.

French civil servants, or fonctionnaires, were the first state workers in a modern industrial nation to organize, unionize and strike. Dr Wishnia studies the period from 1884, when blue-collar workers in France were first permitted to unionize, to 1940 , when the Third Republic collapsed. She focuses on lower-level state workers - postal service employees, teachers, clerks in the finance offices, police - and shows that as the expansion of state employment increased routinization of work and lowered wages, the fonctionnaires became more conscious of their position as hired workers.

\section{Germany}

Hurwitz, Harold, unter Mitarb. von Andreas Büning, Johannes-Berthold Hohmann, Klaus Sühl [und] Ingolore Mensch-Khan. Die Anfänge des Widerstands. Teil 1. Führungsanspruch und Isolation der Sozialdemokraten. Teil 2. Zwischen Selbsttäuschung und Zivilcourage: Der Fusionskampf. [Demokratie und Antikommunismus in Berlin nach 1945, Band IV.] Verlag Wissenschaft und Politik, Köln 1990. 1478 pp. DM 58.00; 68.00 .

This two-volume book is the fourth volume stemming from the so-called Berlin Project of the local Free University (the first three volumes have been noticed in 
IRSH, XXX (1985), pp. 455f.). The central concern of this project is the political development in Berlin immediately following the second World War. The present bulky volume reconstructs the debates and activities of the Social Democratic Party in 1945 as well as the struggle for and against the "unification" of the Social Democratic and Communist organizations in 1946.

Lindemann, Mary. Patriots and Paupers. Hamburg, 1712-1830. Oxford University Press, New York [etc.] 1990. ix, 339 pp. $£ 30.00$.

This monograph analyzes the formation of a modern working class and the changes of bourgeois cultures in the port city of Hamburg, 1712-1830. Issues associated with poor relief are used as springboards to broader debates. The author draws out the shift from an avuncular dirigisme to the laissez-faire of early liberalism and locates this metamorphosis within the framework of Hamburg's fast economic development and demographic growth.

LoRenz, ReInHaRd. Die politische und rechtliche Stellung des Proletariats in Preußen in der Zeit zwischen den Reformen und der Revolution 1848/49. [Rechtshistorische Reihe, Band 94.] Peter Lang, Frankfurt/M. [etc.] 1991. 372 pp. S.fr. 82.00.

This Habilitationsschrift (East Berlin, 1988) sketches the development of the political and legal position of the labour classes in Prussia from the SteinHardenberg reforms until the 1848-49 revolution. The author has paid attention

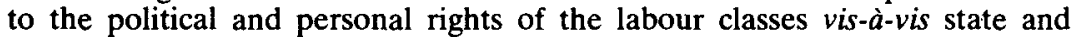
council, the statutory regulations of labour relations, and the criminal measures taken by the state against emancipatory actions of the lower classes.

Mühlbauer, K. R. Zur Lage des Arbeitskindes im 19. Jahrhundert. Ein sozial- und bildungsgeschichtlicher Beitrag unter besonderer Berücksichtigung der Verhältnisse im Königreich Bayern. [Studien und Dokumentationen zur deutschen Bildungsgeschichte, Band 42.] Böhlau Verlag, Köln [etc.] 1991. xii, 383 pp. Ill. DM 58.00.

This Habilitationsschrift (Munich, 1989) describes the life and work of workingclass children in nineteenth-century Bavaria. The author especially provides detailed information about primary education and about "child labour in the pre-industrial and industrial large factory".

Quellen zur Geschichte der deutschen Gewerkschaftsbewegung im 20. Jahrhundert. Begründet von Erich Matthias. Hrsg. von Hermann Weber und Siegfried Mielke. Bund Verlag, Köln.

Band 7. Gewerkschaften in Politik, Wirtschaft und Gesellschaft 1945-1949. Bearb. von Siegfried Mielke und Peter Rütters unter Mitarb. von Michael Becker. 1229 pp. DM 98.00.

This bulky volume is the latest part of an ongoing multi-volume publication of sources concerning the history of the German trade-union movement from 1914 (see IRSH, XXXI (1986), p. 350, XXXII (1987), p. 293 and XXXVI (1991), p. 
144). Volume 7 contains 393 documents about the DGB trade-union confederation 1945-49, its relationship to works councils (Betriebsräte) employers' organizations and political parties.

Hug, Heinz [und] Gerd W. Jungblut. Erich Mühsam (1878-1934). Bibliographie. Topos Verlag, Vaduz 1991. v, 235 pp.

This is a complete bibliography of the writings of the German anarchist Erich Mühsam (1878-1934), who became known by his one-man periodicals Kain and Fanal among other things.

Rohkrämer, Thomas. Der Militarismus der "kleinen Leute". Die Kriegervereine im Deutschen Kaiserreich 1871-1914. [Beiträge zur Militärgeschichte, Band 29.] R. Oldenbourg Verlag, München 1990. 301 pp. DM 78.00.

To many Germans the wars of unification meant a major experience which they would later on remember with pleasure and passion. Based on autobiographical material the present study analyzes the military experiences of labourers, peasants, and lower middle classes, and demonstrates connections between the creation and development of societies of reservists and veterans in the years up to 1914. The nationalistic world view of the "little people" concerned (views on history, state, monarchy, church, private life, etc.) has been reconstructed meticulously.

Sabean, David Warren. Property, production, and family in Neckarhausen, 1700-1870. Cambridge University Press, Cambridge [etc.] 1990. xxiv, 511 pp. $£$ 37.50. (Paper: $£$ 12.95.)

This historical-anthropological study of family relations in a village in southern Germany, 1700-1870, recovers the tenor of marital relationships within a particular context of production and surplus extraction. Arguing for the concept of "property" as a fundamental tool for social analysis, Professor Sabean examines the peculiarities of property devolution, the distribution of tools, and the sale of land.

Sozialgeschichte der Juden in Deutschland. Festschrift zum 75. Geburtstag von Jacob Toury. Hrsg. von Shulamit Volkov [und] Frank Stern. [Tel Aviver Jahrbuch für deutsche Geschichte, Band XX, 1991.] Bleicher Verlag, Gerlingen 1991. 492 pp. DM 78.00.

This special issue of the Tel Aviver Jahrbuch für deutsche Geschichte, at the same time a Festschrift for the Israeli historian Jacob Toury, contains over twenty contributions on the social history of the Jews in Germany. Attention is paid among other things, to the Jewish Question in the early labour movement (Shlomo Na'aman), the antisemitic stereotype (Shmuel Almog), social problems in the Jewish gymnasts' movement about 1900 (Joachim Doron and Gan Shmuel) and Jewish communities in the GDR until 1988 (Peter Maser).

Walter, Franz, Viola Denecke [und] Cornelia Regin. Sozialistische 
Gesundheits- und Lebensreformverbände. [Solidargemeinschaft und Milieu: Sozialistische Kultur- und Freizeitorganisationen in der Weimarer Republik, Band 2.] Hrsg. und eingel. von Peter Lösche, Verlag J. H. W. Dietz Nachf., Bonn 1991. 428 pp. DM 128.00.

This volume of four long essays deals with Social Democratic health and Lebensreform organizations during the Republic of Weimar. Monographic studies have been included of the Verband der Vereine für Volksgesundheit (Franz Walter and Cornelia Regin), the league of abstinents Deutsche Arbeiter-Abstinenten-Bund (Franz Walter), the touristic association Naturfreunde (Viola Denecke) and the Arbeiter-Samariter-Bund (Franz Walter). Registers of persons, places, organizations and newspapers have been appended.

Weitling, Wilhelm. Grundzüge einer allgemeinen Denk- und Sprachlehre. Hrsg. und eingel. von Lothar Knatz. [Philosophie und Geschichte der Wissenschaften, Band 13.] Peter Lang, Frankfurt/M. [etc.] 1991. 320 pp. DM 89.00; S.fr. 73.00.

Wilhelm Weitling (1808-1871) probably was the most important theoretician of early German socialism. The present book contains the scholarly edition of the Grundzüge einer allgemeinen Denk- und Sprachlehre, written in 1856, in which Weitling sketches an encyclopedic classification model and a universal language on the basis of epistemological reflexions. An index to persons has been appended.

\section{Great Britain}

Barret-Ducroco, Françoise. Love in the Time of Victoria. Sexuality, Class and Gender in Nineteenth-Century London. Transl. by John Howe. Verso, London [etc.] 1991. viii, 225 pp. $£ 19.95$.

Using hitherto unpublished first-hand documents, this monograph describes love and sex among the poor in Victorian London. Autobiographical fragments show men and women who are neither depraved nor unusually virtuous: "They meet in the course of their work, in the streets or through family and friends; they seek romance in parks and pubs, servants' attics or rented rooms. The women's own records of their relationships resonate with all the singularities of desire, passion and regret, and they reveal a wide range of responses to separation or abandonment. For, despite their limited options, these women continued to exercise real choice."

Currents of Radicalism. Popular radicalism, organised labour and party politics in Britain, 1850-1914. Ed. by Eugenio F. Biagini and Alastair J. Reid. Cambridge University Press, Cambridge [etc.] 1991. xi, 305 pp. $£ 27.50$.

The eleven essays in this volume stress both the popular elements in Gladstonian Liberalism and the radical and liberal elements in the early Labour Party. The first four papers (by Miles Taylor, Rohan McWilliam, Jon Lawrence and Kenneth D. Brown) focus on the continuity of popular attitudes across the common- 
ly assumed mid-century divide; the following three (by Jonathan Spain, the first editor and Graham D. Goodlad) examine the links between Gladstonian Liberalism and the working classes; the last four papers (by John Shepherd, the second editor, Pat Thane and Duncan Tanner) assess the impact of radical traditions on early Labour politics.

The Eighteenth-Century Town. A Reader in English Urban History 1688-1820. Ed. by Peter Borsay. [Readers in Urban History.] Longman, London [etc.] 1990. viii, 383 pp. £ 10.95.

This Reader gathers together some innovative work on English urban history 1688-1820 that has appeared in research journals. Each piece is prefaced by a brief introduction, highlighting its central features and indicating other publications relevant to it. Besides an extensive introductory essay by the editors eleven articles have been included about, among other subjects: provincial urban culture (the editor), the London 'mob' in the early eighteenth century (Robert B. Shoemaker), the big bourgeoisie of Hanoverian London (Nicholas Rogers) and the role of voluntary societies (R. J. Morris).

Gordon, Eleanor. Women and the Labour Movement in Scotland 1850-1914. Clarendon Press, Oxford 1991. xii, 312 pp. $£ 35.00$.

This is a study of working women in Scotland in the period 1850-1914. Dr Gordon discusses the patterns of their employment, their involvement in and relationship to trade unions and the forms of their workplace resistance and struggles, focusing particularly on women working in Dundee's jute industry. The book challenges assumptions about the organizational apathy of women workers and about the inevitable division between workplace and domestic ideologies.

Hopkins, ERIC. The Rise and Decline of the English Working Classes 1918-1990. A Social History. Weidenfeld \& Nicolson, London 1991. viii, 295 pp. $£$ 18.95. (Paper: $£$ 7.99.)

This monograph provides a comprehensive survey of the changing life and labour of the English working class(es) from 1918 to the present. It deals with working and living conditions, the standard of living, trade unionism, health, poverty, family life, education and leisure activities. It includes economic history in sofar as such history is considered the essential background of social change, as well as the political history of the Labour Party and Labour governments.

JAFFE, JAMES A. The struggle for market power. Industrial relations in the British coal industry, 1800-1840. Cambridge University Press, Cambridge [etc.] 1991. xi, 228 pp. $£ 30.00$.

Using the coal industry in Northern England during the first decades of the nineteenth century as an example, the present book examines the sources of the perception of the market by both capital and labour and the elaboration of their alternative market ideologies. It is argued that working-class culture expressed a fundamental acceptance of the utility of the market. "Thus, industrial relations, including the problems of employment, housing, and production, were charac- 
terized by the attempts to reallocate power in the marketplace between capital and labor, and not, as historians often claim, by conflicts of alternative cultures."

Leneman, Leah. A Guid Cause. The Women's Suffrage Movement in Scotland. [Scottish Women's Studies Series.] Aberdeen University Press, Aberdeen 1991. ix, 304 pp. Ill. £ 11.95.

This history of the women's suffrage movement in Scotland from 1867 to 1914 pays attention to the National Union of Women's Suffrage Societies, the Northern Men's Federation for Women's Suffrage and the cooperation and shifts of allegiance between different suffrage organisations, mainly at the local level. A calendar of events and a list of female activists have been appended.

Marriott, John. The Culture of Labourism. The East End Between the Wars. Edinburgh University Press, Edinburgh 1991. ix, 198 pp. Ill. $£ 35.00$.

The present monograph traces the processes by which the Labour Party came to assume and subsequently maintain power in West Ham, East London. The author argues that the Party's success should not be considered as an automatic response to social and economic grievances, and that it is not due to administrative improvements but to the way the Party articulated and integrated lived experience. Alternative traditions of political activity, including the carnival, a politicized cooperative movement and the large general trade unions all contributed to the Party's initial success.

Randall, Adrian. Before the Luddites. Custom, community and machinery in the English woollen industry, 1776-1809. Cambridge University Press, Cambridge [etc.] 1991. xvii, 318 pp. Ill. Maps. £ 32.50.

The present monograph compares responses to the early introduction of machinery into the English woollen cloth-making industry in the West of England and the West Riding of Yorkshire. The author argues that the organization of work, though very different in each region, gave rise in both to a powerful community culture which put a premium upon custom and stability and which proved hostile to industrial transformation. Dr Randall demonstrates that machine breaking was not a sign of despair but was utilized deliberately and calculatedly as part of a wider organized reaction to displacement.

Urbanising Britain. Essays on class and community in the nineteenth century. Ed. by Gerry Kearns and Charles W. J. Withers. [Cambridge Studies in Historical Geography.] Cambridge University Press, Cambridge [etc.] 1991. ix, 177 pp. $£ 25.00$.

The five essays of this volume consider nineteenth-century urbanization as a process, emphasizing the dimensions of class and community. The contributions are: "Biology, class and the urban penalty" (the first editor), "Public space and local communities: The example of Birmingham, 1840-1880" (Bill Bramwell), "Class, culture and migrant identity: Gaelic Highlanders in urban Scotland" (the second editor), "The country and the city: Sexuality and social class in Victorian Scotland" (J. A. D. Blaikie) and "Mobility, the artisan community and popular 
politics in early nineteenth-century England" (Humphrey Southall).

Wallace, Ryland. Organise! Organise! Organise! A Study of Reform Agitations in Wales, 1840-1886. [Studies in Welsh History, 6.] University of Wales Press, Cardiff 1991. xvi, 267 pp. $£$ 17.95.

This book brings new research to bear on the character, growth and operation of crusading pressure groups and reform movements in Wales during the halfcentury following the Newport Rising of November 1939. The author analyzes some key campaigns, most notably those for parliamentary reform and Nonconformist radicalism, but also the movements for the repeal of the Corn Laws, for trade unions and greater political representation for labour and for women's rights.

Whiteside, Noel. Bad Times. Unemployment in British Social and Political History. [Historical Handbooks.] Faber and Faber, London [etc.] 1991. xii, 147 pp. $£ 5.99$.

This small book is an attempt to show that "unemployment" is a social construction, shaped by social and political forces as much as by economic ones. $\mathrm{Dr}$ Whiteside demonstrates how the nature of unemployment in Britain has changed over time, while demonstrating continuities between past and present debates about the issue.

\section{Hungary}

Gunst, Péter. Die bäuerliche Gesellschaft Ungarns in der Zeit zwischen den beiden Weltkriegen. [Studia Historica, 192.] Akadémiai Kiadó, Budapest 1991.247 pp. $\$ 32.00$.

In this study three aspects of the agrarian sector of Hungarian society in the inter-war years are discussed: its social stratification, including structural and settlement characteristics; income distribution; and conditions of living (housing, food, clothing, hygiene, education).

\section{Italy}

Society and Politics in the Age of the Risorgimento. Essays in honour of Denis Mack Smith. Ed. by John A. Davis and Paul Ginsborg. Cambridge University Press, Cambridge [etc.] 1991. xxi, 279 pp. Maps. $£ 35.00$.

The present volume contains ten essays written in honour of the Italian historian Denis Mack Smith. Topics discussed include the collapse of the ancien régime in southern Italy (the first editor), the Italian armies in the Napoleonic period (Franco Della Peruta), debates on poverty in Italy and Europe in the early nineteenth century (Stuart Woolf), family and marriage (Marzio Barbagli), the origins of the mafia in Sicily (Giovanna Fiume), peasant protest in the Po valley (the second editor), Garibaldi and England in the 1860s (Derek Beales), the emergence of an Italian middle class (Adrian Lyttelton), women workers (Simonetta Ortaggi Cammarosano) and the politics of the critic Francesco De Sanctis (Denis Mack Smith). 


\section{Poland}

Kennedy, Michael D. Professionals, Power and Solidarity in Poland. A critical sociology of Soviet-type society. [Soviet and East European Studies, 79.] Cambridge University Press, Cambridge [etc.] 1991. xiv, 421 pp. $£ 45.00$.

The present book analyzes Solidarnośc on three levels. First, the author attempts to explain the background and nature of the conflict with the authorities by examining the relation between the distribution of power and movement strategies. Second, he considers the implications of Solidarnośc's struggle for the theory of Soviet-type societies. Third, he examines the internal constitution of Solidarność in terms of gender and, in particular, cross-class alliances.

Levine, Hillel. Economic Origins of Antisemitism. Poland and Its Jews in the Early Modern Period. Yale University Press, New Haven [etc.] 1991. xiii, 271 pp. Ill. $\$ 33.00 ; £ 19.95$.

This book presents an analysis of Polish society and its Jews, from the period of that country's greatest territorial expansion and political strength in the sixteenth and seventeenth centuries to the demise of the Polish state in 1795, Professor Levine explains why Poland was not able to modernize its backward social, economic and political system at a time when Western European countries were rapidly evolving, and he shows that Jews were blamed for this failure to modernize, fueling an economic antisemitism.

Roszkowski, WoJCIECH. Landowners in Poland 1918-1939. East European Monographs, Boulder 1991; distr. by Columbia University Press, New York. iii, 203 pp. $\$ 40.50$.

This study attempts to analyze the large landowners in Poland between the two World Wars. The author has paid attention to their social composition (geographic, ethnic, etc.), their political and cultural role, as well as to economic aspects. A list of the two hundred largest landowners in Poland in 1922 has been appended.

\section{Russia - Union of Soviet Socialist Republics}

Between Tsar and People. Educated Society and the Quest for Public Identity in Late Imperial Russia. Ed. by Edith W. Clowes, Samuel D. Kassow, and James L. West. Princeton University Press, Princeton 1991. xv, 383 pp. Ill. \$ 59.50. (Paper: \$16.95.)

This collection of twenty-one essays discusses the relationship between social change in late Imperial Russia - in particular urbanization - and the search for new patterns of social identity that could define and unite "middling" groups. A consensus emerges from the various articles, that the centrifugal forces of intragroup jealousies, traditional loyalties and geographical and ethnic differences were strong and even intensifying. Among the subjects dealt with are: the Riabushinsky circle (the first editor), impediments to a bourgeois consciousness 
(Thomas C. Owen), the Moscow art market (John E. Bowlt), the quest for a modern style in architecture (William C. Brumfield) and the emergence of a middle class (William G. Wagner, Charles E. Timberlake).

McAuley, Mary. Bread and Justice. State and Society in Petrograd 1917-1922. Clarendon Press, Oxford 1991. xviii, 461 pp. Ill. Maps. $£ 45.00$.

This is a study of Petrograd in the period immediately following the Russian Revolution. Using a wide array of original sources, Dr McAuley pictures everyday life in the post-revolutionary city and explores themes such as violence and unemployment, civil justice and bread rations, political ideas and cultural dreams. Lists of leading Petrograd Bolsheviks 1917-1922 and of the Petrograd Committee RKP(b), October 1917-September 1921 have been appended.

McKean, Robert B. St Petersburg Between the Revolutions. Workers and Revolutionaries, June 1907-1917. Yale University Press, New Haven [etc.] 1990. xvii, 606 pp. $\$ 40.00 ; £ 27.50$.

See Reinhart Kössler's review in this volume, pp. 115ff.

Tucker, Robert C. Stalin in Power. The Revolution From Above 1928-1941. W. W. Norton \& Company, New York [etc.] 1990. xix, 707 pp. III. $\$ 36.00$.

This sequel to Professor Tucker's Stalin as Revolutionary, 1879-1929 (see IRSH, XIX (1974), p. 161) focuses on the "revolution from above" from 1929. The author considers Stalin a Bolshevik of the radical Right who blended revolution with a Russian nationalism that led him to find cues for Soviet policy in Russia's distant past, when it was a centralized, state-dominated society. The revolution from above cast the country deep into its past, reviving such tsarist patterns as serfdom, convict labour, imperial expansion in foreign policy, official nationalism in Communist ideology and absolute autocracy.

Die Umwertung der sowjetischen Geschichte. Hrsg. von Dietrich Geyer. [Geschichte und Gesellschaft, Sonderheft 14.] Vandenhoeck \& Ruprecht, Göttingen 1991. 256 pp. DM 48.00.

The "revisionist" tendencies that became apparent among Russian historians in the last few years are examined in the present collection of ten essays. Dealt with are, among other subjects, fresh interpretations of the revolutions of 1905 and 1917 (Manfred Hildermeier), Lenin (Benno Ennker), the 1920s (Eberhard Müller), the collectivization campaign (Stephan Merl) and the nationality question (Uwe Halbach).

\section{Spain}

Martin, Benjamin. The Agony of Modernization. Labor and Industrialization in Spain. [Cornell International Industrial and Labor Relations Series, no. 16.] ILR Press, School of Industrial and Labor Relations, Cornell University, Ithaca 1990 . xvii, 570 pp. $\$ 42.00$. 
See Joseph Harrison's review in this volume, pp. $112 \mathrm{ff}$.

Mitchell, Timothy. Blood Sport. A Social History of Spanish Bullfighting. With an Essay and Bibliography by Rosario Cambria. University of Pennsylvania Press, Philadelphia 1991. xvii, 244 pp. Ill. £ 25.60. (Paper: £ 9.95.)

This monograph on bullfighting holds that it is "no trivial pastime, but the very mirror or Spain's social and historical traumas in the modern period". Dr Mitchell unravels the strands of religion, class conflict, nationalism, political corruption, and machismo that make bullfighting a microcosm of Spanish society.

Rodríguez Labandeira, José. El trabajo rural en España (1876-1936). Prólogo de Miguel Artola. [Historia, Ideas y Textos, 19.] Anthropos, Barcelona; Ministerio de Agricultura, Pesca y Alimentación, Madrid 1991. 462 pp.

This is a comprehensive social and economic history of agricultural labour in Spain, 1876-1936. The book focuses on the labour market and has been divided into four parts: "Supply", "Demand", "The Labour Market" and "State Action and Agrarian Social Policy".

Los sucesos de mayo de 1937. Una revolución en la república. [Por la] Fundación Andreu Nin en colab. con la Fundación Salvador Seguí. Pandora Libros, Barcelona 1988. 254 pp. Ill. Ptas 1000.

The internal conflicts of Republicans that led to armed struggles in Barcelona during the Spanish civil war are the focal point of this collection of documents and short articles. The general trend of the contributions is one of critical solidarity with the anti-Stalinist wing. The extensive documentary section contains, among other items, a report of the meetings of the regional Catalan committee of the CNT, 8-12 May 1937, which has not been published before.

\section{Sweden}

Arbetsliv och arbetarrörelse modern historisk forskning i Sverige. Redaktörer: Klaus Misgeld och Klas Åmark. Arbetarrörelsens arkiv och bibliotek, Stockholm 1991. 124 pp. S.kr. 60.00 (plus postage).

The six contributions to this small volume deal with several aspects of Swedish labour historiography such as working-class daily life (Lars Edgren and Lars Olsson), trade unions and labour markets (the second editor), the Social Democratic Party (Lars Björlin), women and the labour movement (Gunnel Karlsson), workers' educational institutions (Marion Leffler), and a survey of labour history institutions and periodicals (the first editor). An extensive list of relevant publications has been appended.

GADD, CARL-JOHAN. Självhushåll eller arbetsdelning? Svenskt lant- och 
stadshantverk ca 1400-1860. [Meddelanden från Ekonomisk-Historiska Institutionen vid Göteborgs Universitet, 64.] Distr. by: The Institute of Economic History. Gothenburg University, Skanstorget 18, S-411 22 Göteborg 1991. 425 pp. Maps. S.kr. 150.00.

The present book mainly deals with rural crafts and the social division of labour in the Swedish countryside before the middle of the nineteenth century. On the basis of detailed statistical research the author shows in particular that an important part of the rural craftsmen were given purely "agrarian" titles in the tax registers, so that they are hidden from the view of historians: "No doubt Sweden in the 18th and 19th centuries was primarily a rural economy, but it was less uniformly agrarian than has often been thought." An English summary has been appended.

\section{Yugoslavia}

JANCAR-Webster, Barbara. Women \& Revolution in Yugoslavia 1941-1945. [Women and Modern Revolution Series.] Arden Press, Inc., Denver 1990. xvi, 245 pp. Ill. Maps. \$26.50. (Paper: \$16.95.)

See Mira Bogdanović's review in this volume, pp. 121f. 